\title{
Research on the Comparison of Uses of Rhetoric of Public and Private Sector Managers
}

\author{
Assoc.Prof. Mehmet Eymen Eryılmaz \\ Uludağ University, Faculty of Economics and Administrative Sciences, \\ Department of Business Administration, Bursa, 16059, Turkey \\ Email: mehmetery@uludag.edu.tr, mehmeteymen75@gmail.com

\section{Dr. Filiz Eryılmaz} \\ Uludağ University, Faculty of Economics and Administrative Sciences, \\ Department of Economics, Bursa, 16059, Turkey \\ Email: filizgaygusuz@gmail.com
}

Doi:10.5901/mjss.2015.v6n1p165

\begin{abstract}
The differences and similarities between public and private sector organizations and managers comprise a subject that has preoccupied scholars for a long time. However, despite the relatively long history of this subject, it is rather interesting that, to the best of our knowledge, there is no empirical study that thoroughly compares the managers of these sectors in terms of their rhetoric, which is accepted by many management scholars as one of the most important managerial skills. Thus, in this paper, a comparison is made within the Turkish context of the rhetoric used by public and private sector managers during the legitimization process of the management technique "Total Quality Management (TQM)." The data set includes a total of 647 text segments from 238 interviews with managers and articles written by 209 managers. After a rhetorical and statistical analysis, the findings of mixed methods research show that there is no statistically significant difference between the rhetorical legitimization of managers in these two sectors.
\end{abstract}

Keywords: Public sector, private sector, rhetoric, total quality management, Turkey.

\section{Introduction}

The differences and similarities between public and private sector managers and organizations have long preoccupied the literature agenda of "Management-Organization (MO)", political and economic sciences (Boyne, 2002; Rainey et al., 1995; Rainey and Bozeman, 2000). Peculiarly, MO literature has compared managers and organizations of both sectors on many issues, such as organizational commitment, motivational factors, dominant values, and perceptions about role environment and red tape. However, to the best of our knowledge, the managers of these two sectors have not been empirically contrasted in terms of their uses of rhetoric. Despite the fact that communication, especially rhetoric, is accepted as one of the most important skills for managers (Jensen, 2010; Redman and Mathews, 1997) and as one of the activity to which managers allocate most of their time (Donaldson, 2006; Flory and Iglesias, 2010; Green, 2004; Kurke and Aldrich, 1983; Mintzberg, 1975), it is quite interesting that researchers have not placed more emphasis on this subject. In this context, the main aim of this study was to determine whether there are any differences between the uses of rhetoric of public and private sector managers. With this aim, 647 text segments from 238 interviews with public and private sector managers and articles written by 209 public and private sector managers were examined using rhetorical and statistical analyses. It is believed in that results of this study seem to have some benefits for various groups. For example, managers in these two sectors may take some lessons from the results. In addition, findings can contribute to the literature on public-private sector differences and similarities.

Accordingly, the literature focusing on the differences and similarities between these sectors' managers and organizations will be reviewed in the first part of the study. In the second part, the concept of rhetoric, one of the main axes of the study, will be elucidated. The third part addresses the methodology of the study and comprehensively describes the data set, data collection and analysis. The fourth part of the study presents the findings. The study concludes with a discussion of the originalities and limitations of the study. 


\section{The Literature Review on the Comparison of Sectors}

The debate addressing the differences and similarities between public and private sector managers and organizations comprises two axes in terms of their subjects: technical and normative. According to de Graaf and van der Wal (2008), technical debate compares these two sectors' organizations on points such as

(a) media relations and the extent to which actions and policy are subject to public scrutiny; (b) the role of rationality (facts and figures) and emotions in decision-making processes; (c) measurability of performance and effectiveness; (d) time perspective policy development (...); and (e) the mode of finance, political control, and organizational ownership (p.80).

The other debate stream, the normative debate, principally concentrates on the comparison of these two sectors in the context of values and morality (de Graaf and van der Wal, 2008). As emphasized later, because rhetoric is closely related to rationality, emotions and morality, it is fair to say that this study greatly integrates the two streams of this debate.

In a further matter of debate, scholars have argued whether there is any distinction between these two sectors; if the answer is yes, then to what extent can these distinctions be tolerated? In this sense, there appear to be three schools of thought: "Public Administration (PA)," "Business Management (BM)" and "Public Management (PM)" (Gunn, 1988). According to PA, the public sector has a unique and diverse value system and is significantly divergent from the private sector. The private sector has a profit-centered value set, that is, there are few lessons for the public sector that can be taken from private sector organizations and managers' experiences. The second school, BM, considers the public sector to be costly and wasteful and claims that it clearly requires some drastic reforms such as privatization. A less radical suggestion of this school involves the management of the public sector in a more "business-like" way by focusing on the "Five Es (economy, efficiency, excellence, enterprise and effectiveness)" of the private sector. In short, protagonists of this school strongly believe that the forms and practices of organizations in the private sector can be smoothly transferred to the public sector. Finally, PM seems to promote a stance combining the normative and instrumental orientations of PA and BM, respectively. In other words, PM seems to have a perspective that synthesizes the previous two schools' perspectives. As emphasized above, BM advocates the almost direct transmission of management knowledge and techniques from the private sector to the public sector. In contrast, PM defends the idea that "editing" (Sahlin-Andersson, 1996) or "translation" (Czarniawska and Joerges, 1996) of the private sector's knowledge to the public sector may be more appropriate (Dopson and Stewart, 1990; Gunn, 1988).

In addition to theoretical debates, when the findings of empirical studies are examined, it is possible to encounter mixed findings. For example, in contrast to the dominant belief of the literature, it was found in one study that public sector employees tend to value extrinsic factors more than their colleagues in the private sector (Maidani, 1991). In another study of motivation, findings revealed that managers in the public sector generally have a lower level of motivation and that the motivating potential of pay and job security are stronger for private sector managers (Khojasteh, 1993). These findings were interpreted as support for the literature claiming differences between the two sectors in terms of motivation level and factors. Karl and Sutton (1998), in a study that compared the job values of these two sectors' employees, found that employees of both sectors attributed the most importance to factors of "interesting work" and "good wages". Consistent with this finding, research conducted in the Netherlands revealed that public and private sector employees differentiated in terms of their job-related values. While the dominant values in the private sector were profitability, competitiveness and customer orientation, the main values of public sector employees were legitimacy, lawfulness, accountability and impartiality (de Graaf and van der Wal, 2008). Similarly, some research conducted in the human resource management field has drawn attention to various differences between the sectors. For example, a study based on a Turkish sample showed that public and private organizations differ from each other in terms of the name of the department that fulfills human resources functions and the actual functions performed by those departments (Aycan, 2001). In addition, Markovits et al. (2010) examined the relationship between job satisfaction and organizational commitment in the context of private and public sectors. According to their findings, variable of sector significantly moderates this relationship. However, public sector has a stronger effect on this relationship than private sector. Finally, Meier and O'Toole (2011) assumed some differences between these two sectors in terms of range of actions which can be taken by managers inside and outside of their organizations.

By contrast, there are some studies in the literature that provide evidence that there is no remarkable difference between public and private sector managers and organizations. For example, the perceptions of environmental influences held by Israeli managers working for public and private organizations are fairly similar (Lachman, 1985). In another study, it was found that there was no significant difference between the perceptions of goal ambiguity in both sectors (Rainey et al., 1995). Another study revealed that the employees of the two sectors do not show any statistically significant 
difference in terms of the value they attribute to job security (Karl and Sutton, 1998). Buelens and Van den Broeck (2007) found in their research that extrinsic factors have less motivational influence on public sector managers. Furthermore, their findings partially supported the hypothesis that public sector employees are more motivated by a supportive working environment. However, these distinctions stem from job satisfaction rather than the sector itself. The authors interpreted these findings as support for PM.

In summary, a review of the literature presents the overall impression of conflicting findings (Meier and O'Toole, 2011). This conflict may reflect reality, but when the actual situation is closely interpreted, it can be observed that the findings that seem to conflict are not completely inconsistent. For example, if the degree of general formalization is compared, studies frequently present findings indicating either small differences or no difference between the sectors. However, when a specific dimension of formalization is examined, such as personnel or purchasing processes over which external oversight agencies have strong authority, then the degree of formalization in public organizations is higher (Rainey and Bozeman, 2000).

Despite extensive literature on the differences and similarities between these two sectors, there are few theoretical or empirical studies in the literature that focus on sectoral differences in the context of communication behavior. In a study by Mintzberg (1975), which can be accepted as one of the earliest and most important studies in the field, it was hypothesized that public sector managers allocate more time to formal communication. Some of the research that replicated Mintzberg's study in the following years partially confirmed these findings, but some studies did not (for example Kurke and Aldrich, 1983; Kurland and Egan, 1999). In another important study, which endeavored to clarify the differences between the two sectors in terms of communication styles, it was emphasized that public sector managers set vague goals intentionally and transmit them to the related stakeholders ambiguously (Ring and Perry, 1985). Thus, these managers may have a chance to persuade different stakeholder groups that the results of processes are in their favor. In contrast, one of the conditions in the private sector that leads to success is clear goals. Although ambiguous goals may sometimes serve a private organization's purposes, the concept of "strategic ambiguity" appears to be essential, especially for public organizations (Leitch and Davenport, 2002). In a similar vein, Gelders et al. (2007) contend in their theoretical study that the two sectors have fairly unique communication characteristics. According to the authors, these differences can be observed in different dimensions. For example, professionals in the private sector show more sensitivity to images of organizations and their leaders, in contrast to professionals in the public sector. In addition, it has been argued that the criteria used during the evaluation of communication performance are different between these two sectors. Public organizations evaluate their own communication performance not only with criteria such as efficiency and effectiveness but also with criteria such as lawfulness and contributions to democratic ideals. Finally, Meier and O'Toole (2011) asserts that public organizations are often more transparent in their processes and decisions and these are shared with stakeholders to a large extent. On the other hand, secrecy, particularly in the context of strategic management of organization, is more precious for private organizations. Therefore, although there is a divergence in Turkey between these two sectors due to "New Public Management", it is expected that there will be some significant differences between uses of rhetoric of public and private sector managers.

In brief, a few studies that have compared the two sectors in the context of communication behavior refer to two main points. First, the studies indicate that communication behaviors of managers in these sectors seem to be largely different from each other. Second, to the best of our knowledge, there are not many studies that compare these two sectors and their managers in terms of their uses of rhetoric. However, because managers are discursive beings (Green, 2004) and they allocate a large proportion of their time to persuasion efforts (Donaldson, 2006; Flory and Iglesias, 2010; von Koskull and Fougere, 2010), management theoreticians should take language and rhetoric seriously (Karsten, 2006). One study revealed that managers spend an average of $78 \%$ of their time on oral communication (planned meetings, unplanned meetings and telephone calls) (Mintzberg, 1975). In addition, public organizations operate in a context in which many interest groups are involved in management processes. The managers of public organizations endeavor to persuade opposing groups that they are treated fairly (Ring and Perry, 1985). Therefore, persuasion efforts seem to be vital for both of these sectors' managers and organizations.

\section{The Concept of Rhetoric}

The concept of rhetoric has a history of more than two thousand years. During this historical period, rhetoric came to the fore in the Ancient Greek and Roman civilizations. This stream of rhetoric which primarily focuses its interest on orator and his/her message of rhetorical process is called as classical rhetoric. When classical rhetoric is taken up comprehensively, three names become prominent particularly: Aristotle, Plato and Quintilianus (Hamilton, 2000; Meyer, 2009). At other times, such as during the Enlightenment and Romanticism periods, rhetoric lost its popularity (Bonet and 
Sauquet, 2010).

In the history of rhetoric, which is full of rises and falls, Aristotle occupies an important place. Farmer and Patterson (2003: 106) stated, "if anyone was the father, the father of rhetoric was Aristotle." By the same token, the rhetorical approach of Perelman, one of the prominent representatives of "new rhetoric," is an updated version of Aristotelian rhetoric (Bonet and Sauquet, 2010). Aristotle (1991: 13) defined rhetoric as "the ability of 'seeing" the available means of persuasion." Means of persuasion (pisteis) are divided into two subgroups: artistic and non-artistic. The artistic means are invented by the speaker and divided into three sub branches. First, Logos is derived from reasonable argument (Aristotle, 1991; Green et al., 2008; Hamilton, 2003) and a speaker appeals to the logic of audience by emphasizing the words such as goal, efficiency, effectiveness, productivity, system, method and science. Pathos is derived from the emotions (such as compassion, fear, greed, jealousy, loyalty, ruthlessness and so on) aroused in an audience by a speaker. Finally Ethos is derived from the character of the speaker when he presents himself to an audience as a trustworthy person during a speech. Ethos largely focuses on matters such as moral, ethic, traditions, rights, justice ad so on. Logos and Pathos address individual interests, and they produce "pragmatic legitimacy" (Suchman, 1995), whereas Ethos emphasizes socially accepted norms and traditions and produces "moral legitimacy" (Green, 2004).

Along with the "Linguistic Turn" in social sciences (Alvesson and Kärreman, 2000a, 2000b; Green, 2004), beyond the information exchange, the role of language in the construction of reality and subjectivity has become prominent (Heracleous and Barrett, 2001; Knights and Morgan, 1991). Consequently, an increased interest in rhetoric has appeared in MO literature in recent years (Jensen, 2010). A review of the literature reveals that it is possible to encounter different conceptualizations of rhetoric (e.g., Abrahamson, 1997; Barley and Kunda, 1992). For instance, the concept of rhetoric has sometimes been used as a tool of control, power and manipulation (Flory and Iglesias, 2010; Hartelius and Browning, 2008). Despite alternative approaches in the literature of rhetoric (for example Brimeyer et al., 2004; King and Kugler, 2000), many studies (e.g., Eryılmaz and Eryılmaz, 2011; Green, 2004; Green et al., 2008; Green et al., 2009; Hamilton, 2003; Özen and Berkman, 2007; Suddaby and Greenwood, 2005) seem to adopt a conceptualization parallel to that of Aristotle. In addition, given the recognition of Aristotle as the fountain of rhetoric, this study is based on an Aristotelian conceptualization. Therefore, this study defines rhetoric as the art of persuasion.

These rhetoric can be used by various actors, such as scholars (Alvarez, 1998); management gurus (Özen, 1999); consulting firms (Arias and Guillén, 1998; Crucini and Kipping, 2001; Mazza, 1998); politicians (Alvarez, 1998); mass, professional and business media (Frenkel, 2005; Rüling, 2005; Sahlin-Andersson and Engwall, 2002; Scarbrough et al., 2005); and professional managers (Jarzbowski and Sillience, 2005; Özen and Berkman, 2007). There may be some differences between the groups of actors in terms of their primary rhetoric. For example, it is expected that scholars and management gurus primarily prefer logos and pathos rhetoric, respectively, in an effort to persuade (Mazza, 1998; Özen, 1999). In this study, the rhetoric of public and private managers are examined in the context of "Total Quality Management (TQM)" legitimization in Turkey. At this point, it should be emphasized that speakers (managers) in this study seem to legitimize TQM. They substantially legitimize their organizations indirectly which use TQM as well.

Context is a "stimuli and phenomena that surround and thus exist in the environment external to the individual, most often at a different level of analysis" (Johns, 2006: 386 cited from Mowday and Sutton, 1993: 198). A common idea is that speaker and context are independent of each other. However, separating texts from developments in local and general contexts is not a healthy approach (Hammersley, 1997; Symon, 2000). Understanding a cause and effect relationship between context and rhetoric (or speaker) is important. By this means, changing rhetoric of speakers in terms of changing contextual factors can be understood all the better. When the literature is reviewed, it can be observed that studies in classical rhetoric have a richer emphasis on context. For example, "kairos" (sensitivity to time or the opportune moment) and "decorum" (fitting the argument to the both to the moment and the audience) (Suddabby and Greenwood, 2005: 44) are concepts frequently encountered in classical rhetoric. In sum, as emphasized by Nugus (2009), rhetoric is embedded in context. In other words, discourses and rhetoric which presents persuasive parts of a discourse (Jarzabkowski and Sillince, 2007) are largely affected by characteristics of context and changes in it.

In the literature, there are some studies (e.g. Barley and Kunda, 1992; Abrahamson, 1997) which underline the importance of context during determination of an appropriate rhetoric for context. For example, Barley and Kunda (1992) specified five waves which made their marks on management thought of United States of America between the 1870s and the 1990s. According to them, three of these five waves (industrial betterment, welfare capitalism/human relations and organizational culture) can be gathered under normative rhetoric. The other two waves (scientific management and systems rationalism) can be thought under rational rhetoric. The main idea of normative rhetoric is to invest in emotions of workers to increase their productivity. Therefore, normative rhetoric uses metaphors such as family, group, team and culture. On the other hand, the main idea of rational rhetoric is that management should rationalize and formalize business processes to attain organizational goals. Thus, rational rhetoric benefits from metaphors such as organization 
as a machine and worker as a gear of this machine or organization as a system and worker as a node of this system (Barley and Kunda, 1992). In a similar vein, Eryllmaz and Eryllmaz (2011) found that rhetoric of top managers in holding companies of Turkey which is used to legitimize directly TQM and indirectly agents' position against principals in their organizations are readjusted partially during the terms of economical crisis in Turkey. Variable of "sector" is an important part of context. Therefore, it is expected that there will be significant differences between uses of rhetoric of two sector managers. For example, managers of private sector organizations may prefer to use more logos rhetoric in their persuasion efforts. On the hand, it may be expected that public sector managers obtain much benefit from ethos rhetoric.

\section{Methodology}

\subsection{Data}

The data set of this study comprises persuasive text segments from articles (written by managers) and interviews (conducted with managers) that were published in "Önce Kalite (Quality is First)" between 1992 and 2010. In these articles and interviews, managers from public and private sectors endeavored to directly legitimize TQM (and indirectly legitimize their organizations which use TQM) in a Turkish context. TQM, which has been described using the metaphor of a "virus" in international arenas (Pastor et al. 1998), entered the Turkish context in a period when the government had adopted an import substitution economy policy via the contributions of professional managers of holding organizations (Özen, 2002) and KalDer (Quality Association) (Yıldırım, 1999). The reason for the selection of TQM in the present study is that this technique has reached the height of its interest in Turkey (Özen, 2002) and has almost become a social movement. Intensive attention to TQM coming from almost every segment of society has allowed for some comparisons among different individuals, groups and organizations. "Önce Kalite," which forms the basis for the data set, has been published by the Turkish Quality Association since 1992 and is the first and only quality management journal in Turkey. However, the journal was not published in 1993 and 1996, so the data for those two years could not be incorporated into this study. After the examination of more than 10,000 pages of text, 647 TQM-legitimizing text segments were found in articles and interviews from 209 managers. Of the text segments, 433 originated from private sector managers and 214 from public sector managers. At this point, to decide on that whether an organization is public or private, we mainly benefited from various sources. At the first point, we assessed organizations in terms of criteria of publicness. Three factors under criteria of publicness are offered by the literature such as ownership, sources of financial resources and model of social control (Boyne, 2002; Meier and O'Toole, 2011). When we had adequate information about these factors, we decided on that whether an organization is public or private. However, if they didn't have, it was also researched that whether text contains a declaration of manager about sector of his/her organization or not. Finally, if we didn't find any information in the text about sector of organization, we visited web sites of these organizations and we based on statements in their web sites about sector of organization. The managers comprised 154 males (74\%) and 55 females (26\%) with an average age of 46 years at the time of publication in the journal. Of the total 209 managers, $137(66 \%)$ worked in the private sector and 72 (34\%) in the public sector.

\subsection{Method of Analysis}

The analysis part of the study consists of two sub-sections: rhetorical analysis and statistical analysis. This mixed methodology was chosen. Because it was thought that a qualitative study might be more appropriate to examine communication behaviors of managers. At the same time, we needed a statistical analysis to understand that whether there are some significant differences in terms of communication behaviors of two sectors or not. The first part is related to rhetorical analysis, in which 2 researchers experienced in rhetorical analysis tried to identify the text segments within the articles and interviews that included persuasion efforts about TQM. When there was indecision about a text segment as to whether it should be included in the data set, the final decision was made by consensus. At this point, sentences interrelated and logically formed integrity were accepted as text segments and these text segments varied in length from a sentence to a paragraph. During this process, some text segments that did not contain any legitimizing rhetoric were excluded from the study. All text segments which contain a legitimizing rhetoric were included in the study.

During the subsequent stage, the researchers analyzed the types of rhetoric in these text segments by creating a coding scheme with the support of "rhetoric in TQM" studies (e.g., Green, 2004; Green et al., 2009; Özen and Berkman, 2007). For example, when the emphasis was on the relationship between TQM and concepts such as efficiency, effectiveness, profit, science, etc., it was generally accepted that this text segment included logos rhetoric. In a similar vein, for example, there were some texts that emphasized that global competition was terrorizing the world. In these 
texts, managers strived to persuade the readers by activating their emotion of fear. Therefore, it was regarded that these texts contained pathos rhetoric. Lastly, in the context of ethos rhetoric, it was observed that Turkish managers, by benefiting from "macro discourses" (Lawrence and Phillips, 2004), tried to legitimize TQM (Özen and Berkman, 2007) with an emphasis on several concepts, such as the prophet Muhammad, the ideology of Kemalism, the traditional sympathy of Turks for the Japanese, high democratic ideals and so forth. However, this coding scheme was not completely rigid. Because rhetoric is embedded in context as underlined above. For instance, if "participative management" was used as a tool to increase organizational effectiveness, it was allocated to logos rhetoric in this context. By contrast, if it was used as a contribution to the ideals of democratization of society, it was regarded as an example of ethos rhetoric. In another example, if "employee satisfaction" was preferred as a tool to achieve the goal of productivity, it was assigned to logos rhetoric again. However, if it was used as a contribution to well-being of employee, it was regarded as an example of pathos rhetoric. In addition, these means of persuasion are frequently used jointly (Bonet and Saquet, 2010). Therefore, the presence of rhetorical combinations in the text segments was also examined (a rhetorical combination may contain two or three means of persuasion such as "logos + pathos" or "logos + pathos + ethos"). Furthermore, in some studies of rhetoric (e.g., Erkama and Vaara, 2010; Suddaby and Greenwood, 2005; von Koskull and Fougere, 2011), extra means of persuasion were added to support Aristotelian rhetoric. Thus, this study examined whether Aristotelian means of persuasion were adequate to explain all of the persuasion efforts in these texts. All of the persuasion efforts were examined; however, any text segment which couldn't be gathered under Aristotelian means of persuasion couldn't be found. Therefore, the researchers decided that Aristotle's rhetorical categorization was adequate, and thus, they did not need to add any new rhetorical categories.

The researchers utilized several tactics to increase the validity and reliability of the research. First, the researchers had to decide "which articles should have been accepted as a TQM article," and if TQM was an umbrella term, then "which techniques and tools should have been dealt with under this umbrella?". It is known that several definitions are used to describe TQM, and these definitions may have different meanings for different individuals and groups (Hackman and Wageman, 1995). Therefore, inspired by Abrahamson (1997), the keyword of "Total Quality Management" was entered into a database, and the abstracts and keywords of first 1,000 TQM articles were examined. The first 1,000 hits were selected since they were ranked in terms of relevance with TQM. After this examination, a set of concepts related to TQM was obtained (e.g., quality, quality assurance, quality control, quality management, quality management system, continuous improvement, employee involvement, customer satisfaction, teamwork). This set of concepts was largely consistent with both previous studies on rhetoric in the TQM field (e.g., Green et al., 2009) and seminal books of TQM (e.g., Deming, 1996; Ishikawa, 1985). Another tactic used was the calculation of reliability. The two researchers independently coded the randomly selected 203 text segments which contain rhetoric. Because this number of text segments was $31 \%$ of the total number of text segments which include rhetoric about legitimization, the sample size could be accepted as adequate (Neuendorf, 2002). Two researchers coded 203 text segments independently and then, coding about rhetoric of two researchers was compared. After calculation, the inter-rater reliability coefficient was found to be 0.80 , which was an acceptable level (Tavşancll and Aslan, 2001). As another tactic, while the researchers were assigning text segments to Aristotelian rhetorical categories, evidence was sought in the remainder of the article to confirm their assignment. For example, if the researchers thought that the concept of "quality of life" was used by a manager in the context of pathos rhetoric, then the rest of the interview was examined to support that categorization, and after similar expressions to the one below were found, the decision was supported:

In my opinion, appreciation, admiration, praise and even jealousy are appropriate words to describe the concept of quality life. (Aybar, 2003: 21). (Italics were added by the researchers).

In the second part of the analysis, each rhetoric used by a manager was categorized by the total number of rhetoric used by this manager in the texts. In this way, a proportion was obtained for every manager and every category of rhetoric. Such a standardization procedure was necessary because the length of articles and interviews varied greatly. Then, the data belonging to public and private sectors were examined regarding whether the data for each category of rhetoric were distributed normally. The findings showed that the data were not normally distributed. Furthermore, during the comparisons between the public and private sectors, some variables, such as age, gender, education and organization size, needed to be checked (Buelens and Broeck, 2007; Lachman, 1985) to increase the scientific rigor of the research. The analysis conducted by the researchers indicated that there was no statistically significant difference between the groups in terms of the age of the managers. Moreover, all of the managers had an educational level of a university degree or beyond, and they all held top management positions in their organizations. Equivalence between groups in terms of hierarchical positions is a critical point because some research (e.g., Buelens and Broeck, 2007; Karl and Sutton, 1998) has shown that there may be some differences between managers and non-management employees. Although the findings of previous meta-analyses (e.g., Wilkins and Andersen, 1991) have indicated that there is no 
significant difference between genders in terms of communication behavior, the researchers compared male and female managers in the study in the context of the use of rhetoric, and a significant difference was not found. Another variable that may have some impact on managerial behaviors is organization size; it was observed in a previous study that as organizations grow, managers of organizations begin to allocate more time to external relations (Kurke and Aldrich, 1983). However, there was no significant difference between the sectors in terms of organization size. Because the data were not distributed normally, the Mann-Whitney U test was implemented.

\section{Findings}

Rhetorical themes are the main strategy used by text segments to legitimize a management technique or organizational form (Özen and Berkman, 2007). Rhetorical analysis revealed that the most frequently encountered 10 themes in the text segments were "survival in global competition", "quality of life", "psychology of employees", "efficiency and effectiveness", "low costs", "reaching the level of contemporary civilizations", "quality as a life style", "industrial democracy", "competitive power of country", and "relationships between quality and the European Union process of Turkey". Some examples regarding these themes are presented below:

In a globalizing world, evolution of intensive competition from a national level to an international one has necessitated the adaptation of organizations to this new order. Surviving in a competitive environment, which can be perceived as a high subscripted puzzle, depends on the amount and capacity of brainpower that organizations possess. Having a voice in the market is contingent upon the importance of the human factor for organizations. Therefore, organizations should adopt management styles that draw advantage from both the physical and brain power of the employees. Among the systems attributing importance to employees, TQM is the most appropriate one. (Alptekin, 1999: 19). (An interview with a manager of a private organization).

Preemptively, organizations should consider TQM as industrial democracy. (Kon, 2002: 13). (An interview with a manager of a private organization).

We aim to fulfill our mission, which is "to contribute to the enhancement of the competitive power of Turkey using science and technology, by sharing our experiences concerning TQM besides our knowledge about science and technology. (Görür, 2003: 14). (An interview with a manager of a public organization).

The descriptive statistics and distributions regarding rhetoric are presented in Table 1. The findings show that when both public and private managers use only one type of rhetoric, the most preferred and least rhetorical categories are logos and ethos respectively. The most frequently used rhetoric for both sectors is a combination of logos, pathos and ethos. However, this result is interpreted cautiously since it is the rhetoric which has the biggest standard deviation.

Table 1: Descriptive statistics concerning the rhetoric that managers prefer

\begin{tabular}{|c|c|c|c|c|c|c|c|}
\hline & $\mathrm{N}$ & $\mathrm{M}(\%)$ & $\mathrm{SD}$ & Max. & Min. & Private (\%) & Public (\%) \\
\hline Logos & 209 & 15.79 & 26.31 & 100.00 & .00 & 16.02 & 15.33 \\
\hline Pathos & 209 & 10.86 & 22.21 & 100.00 & .00 & 10.51 & 11.49 \\
\hline Ethos & 209 & 9.51 & 21.46 & 100.00 & .00 & 8.57 & 11.26 \\
\hline Logos + Pathos & 209 & 19.82 & 30.37 & 100.00 & .00 & 21.62 & 16.37 \\
\hline Logos + Ethos & 209 & 11.52 & 24.50 & 100.00 & .00 & 10.22 & 14.00 \\
\hline Pathos + Ethos & 209 & 10.34 & 22.81 & 100.00 & .00 & 9.33 & 12.25 \\
\hline Logos + Pathos + Ethos & 209 & 22.35 & 31.52 & 100.00 & .00 & 23.33 & 19.30 \\
\hline
\end{tabular}

Some examples with regard to rhetoric and combinations are presented below:

Obtained benefits of TQM implementation for an organization are observed in improvement in main performance indicators. Progress is materialized in both sales-unit costs and customer and employee satisfaction criteria. (Bingöl, 2000: 19). (Logos rhetoric). (An interview with a manager of a private organization).

When the extant structures and resources are taken into consideration, quality management systems have become imperative for public organizations. (Hacıoğlu, 2003: 20). (Pathos rhetoric). (An interview with a manager of a public organization).

Openness of the Turkish society that adopts modernization as a core principle to system approaches to TQM gives way to contemporary education. (Sarı, 2003: 37). (Ethos rhetoric). (An interview with a manager of a public organization).

After TQM implementation, our working environment, from the teachers' lounge to the conference hall, was greatly improved. Since the conference hall was modified, when I enter into it I feel good. In addition, common exams were 
fulfilled in common and everything has become more planned... Our question bank was extended, and the quality of exam questions was improved. (Bilge, 2004: 34). (Logos rhetoric + Pathos rhetoric). (An interview with a manager of a public organization).

I believe that Total Quality Management will play an important role in the enhancement of the competitive power of Turkey. In addition, TQM can make this contribution without resource support from abroad. Therefore, TQM is as important in [national] development as other channels that do not need extra resources. (Uzer, 2002: 20). (Logos rhetoric + Ethos rhetoric). (An interview with a manager of a private organization).

We aim to be an organization adding value to society with all its activities and employees, who prioritize business ethics and respect to self, human and environment. In our competitive world, to be a leader of the sector and to sustain this leadership, we determined our direction with the slogan of "Total Quality is work of high quality people." (Bingöl, 2000: 19). (Pathos rhetoric + Ethos rhetoric). (An interview with a manager of a private organization).

In my opinion, "Total Quality Management" is an entity of structured, continuous and systematic workings and improvements and in which an organization creates value for shareholders, customers, employees, suppliers, society and environment and strives to maximize the satisfaction of the above-cited stakeholders. (Öker, 2003: 19). (Logos rhetoric + Pathos rhetoric + Ethos rhetoric). (An interview with a manager of a private organization).

In Table 2, the findings of the Mann-Whitney $U$ Test are presented. The findings demonstrate that there are no statistically significant differences between the managers of the two sectors in terms of uses of "logos" ( $U=4809 ; p=.807)$, "pathos" ( $U=4824 ; p=.745)$, "ethos" ( $U=4656.5 ; p=.389)$, "logos+pathos" ( $U=4390 ; p=.147)$, "logos+ethos" ( $U=4817.5$; $p=.722)$, "pathos+ethos" ( $U=4684 ; p=.505)$ and "logos+pathos+ethos" ( $U=4201.5 ; p=.079)$ rhetoric. The closest value to statistical significancy is about uses of "logos+pathos+ethos" rhetoric by two sectors' managers.

Table 2: The findings of the Mann-Whitney $U$ test

\begin{tabular}{|c|c|c|c|c|c|c|c|}
\hline & Logos & Pathos & Ethos & Logos+Pathos & Logos+Ethos & Pathos+Ethos & Logos+Pathos+Ethos \\
\hline Mann-Whitney U & 4809 & 4824 & 4656.5 & 4390 & 4817.5 & 4684 & 4201.5 \\
\hline Wilcoxon W & 14125 & 14277 & 14109.5 & 7018 & 14270.5 & 14000 & 6757.5 \\
\hline Z & -.244 & -.326 & -.862 & -1.450 & -.356 & -.666 & -1.758 \\
\hline Asymp. Sig. (2-tailed) & .807 & .745 & .389 & .147 & .722 & .505 & .079 \\
\hline
\end{tabular}

a Grouping Variable: Sector

\section{Conclusion}

The main purpose of this study was to investigate whether there were any differences between Turkish private and public sector managers in terms of preferred rhetoric. With this aim, an analysis was performed on 647 text segments, which were attempting to legitimize TQM in a Turkish context, from 238 interviews and articles that came from a total of 209 private and public sector managers.

The findings of the rhetorical analysis showed that when managers used only one type of rhetoric, both groups preferred logos rhetoric. When the researchers conducted a semi-structured interview with the current editor of "Önce Kalite," they learned that before 2004, it was a refereed journal. The peer review process may explain the popularity of logos rhetoric among managers. The most frequently used themes in logos rhetoric are results-related themes such as productivity, efficiency and effectiveness. Although "being scientific" is one of the most preferred themes by managers, it was used less frequently compared with results-based themes. One attractive management technique, the provision of a guarantee of the desired business results, is considered adequate even though there is no clear proof of its scientific value (Karsten, 2006 cited from Grint, 1992). Thus, in this study, the focus of managers on business results stemming from TQM in order to legitimize the TQM seems to be consistent with this claim. In addition, in many developing countries, the transfer of management knowledge is accepted as a prerequisite for economic progress at the national level (Üsdiken, 1997). In this context, the frequent use of themes such as "economic progress" and "to reach the level of contemporary civilization," both considered ethos rhetoric, supports this idea.

Another finding of the study that was consistent with literature (e.g., Bonet and Saquet, 2010) was that the most preferred type of rhetoric for both sectors was a combination of the three rhetoric (logos + pathos + ethos). According to a previous study, private sector managers use logos rhetoric twice as often as they use ethos rhetoric. By contrast, public sector managers tend to balance logos rhetoric with ethos rhetoric. Therefore, there are some differences between the sectors in terms of their preferences for rhetoric, although they seem to be at a negligible level. Therefore, the findings are partially consistent with PM. 
The findings of the rhetorical analysis were then quantified and standardized. The Mann-Whitney U Test indicated that there were no statistically significant differences between the sectors in terms of rhetorical uses. There are several possible explanations for this result. For example, scholars asserting sectoral differences frequently hold a priori assumptions in this context (Rainey and Bozeman, 2000). Therefore, claimed communication and language differences might be exaggerated. The second reason may be the effect of the "New Public Management (NPM)" approach, which has spread rapidly across Turkey since the 1990s. The effect of this development may have caused a convergence between the two sectors.

One of the original points asserted in this study indicated that even though managers allocate a large proportion of their time to communication and persuasion (Bonet and Sauquet, 2010; Flory and Iglesias, 2010; Karsten, 2006; Kurke and Aldrich, 1983; Mintzberg, 1975), to the best of our knowledge, there is no comparative inter-sector empirical study on this point in the literature. Some studies in the literature claim that rhetoric is the main axis of management (von Koskull and Fougere, 2010), although there is a noticeable lack of studies concerning rhetoric in this field. Another original point of this study is the applied research method, which is unique from those used in other studies in the field. Because mixed methods research is described as a design in which qualitative and quantitative data are collected, analyzed and integrated (Creswell and Cresswell, 2005), this study can be regarded as an example of mixed methodology. In social sciences, studies based on mixed methods research indicate the future of research within many fields (e.g., Powell et al., 2011). In this context, the present study appears to be one of the few mixed-methodology studies in the field. Finally, previous studies of rhetoric have been largely conducted in the context of developed countries; thus, this is one of the few studies of rhetoric in the context of a developing country.

There is no doubt that, as in all studies, this study has some limitations. For example, the study sample makes generalization difficult. Therefore, subsequent research should be conducted at a cross-cultural level and with larger samples. Second, the study is based on a data set starting from 1992. If the study had a longer data set, it would have been able to test whether this similarity in rhetoric of managers has been consistent over time or if it emerged after the rise of NPM in Turkey. Third, managers in the study were members of different industries. Although there are some studies indicating that top managers of different industries may show important similarities in their communication behaviors (Kurke and Aldrich, 1983), comparing managers from same industry would yield stronger conclusions. Finally, this study has accepted the two sectors as homogenous structures. However, inside these sectors, there may be important differences (Liu et al., 2010) that should be taken into account.

Finally, this study highlights several implications for managers. First, attention is given to the importance of the rhetorical and communication skills of managers. With a stronger understanding of the importance of language in organizational processes, the coordination and problem-solving skills of managers can be strengthened (Karsten, 2006), thus increasing the performance of managers and organizations. Second, although this point of research needs more extensive study, the findings of this study seem to provide some insights for managers who plan to change sectors. Because there are important similarities in the rhetoric of both sectors, those managers changing sectors can direct their current rhetoric to new target audiences with small modifications.

\section{References}

Abrahamson, E. (1997). The emergence and prevalence of employee management rhetorics: the effects of long waves, labor unions and turnover, 1875 to 1992. The Academy of Management Journal, 40(3), 491-533.

Alptekin, C. (1999). Girişimcilik, inanç ve TKY ödül getirdi. Önce Kalite, Temmuz-Ağustos, 18-19.

Alvesson, M. \& Kärreman, D. (2000a). Taking the linguistic turn in organizational research: challenges, responses, consequences. Journal of Applied Behavioral Science, 36, 136-158.

Alvesson, M. \& Kärreman, D. (2000b). Varieties of discourse. On the study of organizations through discourse analysis. Human Relations, Vol.53, No.9, 1125-1149.

Arias, M.E. \& Guillén, M. (1998). The transfer of organizational techniques across borders: combining neo-institutional and comparative perspectives. In J.L. Alvarez (Ed.) The Diffusion and Consumption of Business Knowledge. London: Macmillan.

Aristotle (1991). Aristotle on Rhetoric: A Theory of Civic Discourse. New York: Oxford University Press (Translated by George A. Kennedy).

Aybar, I. (2003). Lider, fikirleri ile toplumları etkileyebildiği ölçüde liderdir (interview). Önce Kalite, Mart, 21.

Aycan, Z. (2001). Human resource management in Turkey: current issues and future challenges. International Journal of Manpower, 22(3), $252-260$.

Barley, S.R. \& Kunda, G. (1992). Design and devotion: surges of rational and normative ideologies of control in managerial discourse. Administrative Science Quarterly, 37(3), 363-399.

Bingöl, N. (2000). Wolkswagen elektrik sistemleri (interview). Önce Kalite, Kasım-Aralık, 18-19.

Bonet, E. \& Sauquet, A. (2010). Rhetoric in management and in management research. Journal of Organizational Change Manageme nt, 23(2), 120-133. 
Boyne, G.A. (2002). Public and private management: what's the difference? . Journal of Management Studies, 39(1), 97-122.

Bozeman, B. (1987). All Organizations are Public. London: Jossey Bass.

Brimeyer, T.M., Eaker, A.V. \& Clair, R.P. (2004). Rhetorical strategies in union organizing: A cases of labor versus management. Management Communication Quarterly, Vol. 18, No.45, 46-74.

Buelens, M. \& van den Broeck, H. (2007). An analysis of differences in work motivation between public and private sector organizations. Public Administration Review, January/February, 65-74.

Creswell, J.W. \& Creswell, J.D. (2005). Mixed methods research: developments, debates and dilemmas (pp.315-326). In R.A. Swanson \& E.F. Holton III (Eds.). Research in Organizations: Foundations and Methods of Inquiry. San Francisco: Berrett-Koehler Publishers.

Crucini, C. \& Kipping, M. (2001). Management consultancies as global change agents?: evidence from Italy. Journal of Organizational Change Management, 14(6), 570-589.

Czarniawska, B. \& Joerges, B. (1996). Travels of ideas (pp.13-48). In B. Czarniawska \& G. Sevon (Eds.). Translating Organizational Change. Berlin: Walter de Gruyter.

de Graaf, G. \& van der Wal, Z. (2008). On value differences experienced by sector switchers. Administration \& Society, 40(79), 79-103.

Deming, W.E. (1996). Krizden Çıkış. İstanbul: Arçelik A.Ş.

Donaldson, L. (2006). The contingency theory of organizational design: challenges and opportunities (pp.19-40). R.M. Burton, B. Eriksen, D.D. Hakonsson \& C.C. Snow (eds.) Organization Design: The Evolving State-of-the-Art, Springer.

Dopson, S. \& Stewart, R. (1990). Public and private sector management: the case for a wider debate. Public, Money \& Management, Spring, 37-40.

Erkama, N. \& Vaara, E. (2010). Struggles over legitimacy in global organizational restructuring: a rhetorical perspective on legitimation strategies and dynamics in a shutdown case. Organization Studies, 31, 813-839.

Eryılmaz, M. \& Eryılmaz, F. (2011). Ekonomik krizlerin retoriksel stratejilere etkisi: TKY örneği. Yönetim Araştırmaları Dergisi, 11/1-2, 35-78.

Euske, K. (2003). Public, private, not-for-profit: everybody is unique?. Measuring Business Excellence, 7(4), 5-11.

Farmer, D.J. \& Patterson, P.M. (2003). The reflective practitioner and the uses of rhetoric. Public Administration Review, 63(1), $105-111$.

Flory, M. \& Igleias, O. (2010). Once upon a time: the role of rhetoric and narratives in management research and practice. Journal of Organizational Change Management, 23(2), 113-119.

Frenkel, M. (2005). Communicating management: the role of the mass idea in the institutionalization of professional management and productivity discourse in Israel. Scandinavian Journal of Management, 21, 137-157.

Gelders, D., Bouckaert, G. \& van Ruler, B. (2007). Communication management in the public sector: consequences for public communication about policy intentions. Government Information Quarterly, 24, 326-337.

Görür, N. (2003). Misyonumuzu TKY'nin ışığında gerçekleştireceğiz. Önce Kalite, Temmuz, 14-15.

Green, S.E. (2004). A Rhetorical Theory of Diffusion. Academy of Management Review, 29(4), 653-669.

Green, S.E, Babb, M. \& Alpaslan, C.M. (2008). Institutional field dynamics and the competition between institutional logics: the role of rhetoric in the evolving control of the modern corporation. Management Communication Quarterly, 22(40), 40-73.

Green, S.E., Li, Y. \& Nohria, N. (2009). Suspended in self-spun webs of significance: a rhetorical model of institutionalization and institutionally embedded agency. Academy of Management Journal, 52(1), 11-36.

Gunn, L. (1988). Public management: a third approach?. Public Money \& Management, Spring-Summer, 21-25.

Hacıoğlu, F. (2003). Kamuda kalite çalışmaları. Önce Kalite, Temmuz, 20-21.

Hackman, J.R. \& Wageman, R. (1995). Total quality management: empirical, conceptual and practical issues. Administrative Science Quarterly, 40, 309-342.

Hamilton, P.M. (2000). Attaining agreement: a rhetorical analysis of a NHS negotiation. The International Journal of Public Sector Management, Vol.13, No.3, 285-300.

Hamilton, P.M. (2003). The vital connection: a rhetoric on equality. Personnel Review, 32(6), 694-710.

Hammersley, M. (1997). On the foundations of critical discourse analysis. Language and Communication, Vol.17, No.3, $237-248$.

Hartelius, J.E. \& Browning, L.D. (2008). The application of rhetorical theory in managerial research: a literature review. Management Communication Quarterly, 22, 13-39.

Heracleous, L. \& Barrett, M. (2001). Organizational change as discourse: communicative actions and deep structures in the context of information technology implementation. Academy of Management Journal, 44(4), 755-766.

Ishikawa, K. (1985). What is Quality Control?: The Japanese Way. New Jersey: Prentice Hall.

Jarzabkowski, P. \& Sillince, J. (2007). A rhetoric-in-context approach to building commitment to multiple strategic goals. Organization Studies, 28, 1639-1665.

Jensen, H.S. (2010). Management -decision and interpretation. Journal of Organizational Change, 23(2), 134-136.

Johns, G. (2006). The essential impact of context on organizational behavior. Academy of Management Review, 31(2), $386-408$.

Karl, K.A. \& Sutton, C.L. (1998). Job values in today's workforce: a comparison of public and private sector employees. Public Personnel Management, 27(4), 515-527.

Karsten, L. (2006). Management concepts: their transfer and implementation. Critical Perspectives on International Business, 2(3), $195-207$.

Khojasteh, M. (1993). Motivating the private vs. public sector managers. Public Personnel Management, 22(3), 391-401.

King, W.R. \& Kugler, J.I. (2000). The impact of rhetorical strategies on innovation decisions: an experimental study. Omega, 28, 485-499.

Knights, D. \& Morgan, G. (1991). Corporate strategy, organizations, and subjectivity: a critique. Organization Studies, 12(2), $251-273$.

Kon, B. (2002). Toplam kalite yönetimi endüstriyel demokrasidir (interview). Önce Kalite, Mart, 13.

Kurke, L.B. \& Aldrich, H.E. (1983). Mintzberg was right!: a replication and extension of the nature of managerial work. Management Science, 
29(8), 975-984.

Kurland, N.B. \& Egan, T.D. (1999). Public vs. private perceptions of formalization, outcomes, and justice. Journal of Public Administration Research and Theory, 9(3), 437-458.

Lachman, R. (1985). Public and private sector differences: CEO's perceptions of their role environments. The Academy of Management Journal, 28(3), 671-680.

Lawrence, T.B. \& Phillips, N. (2004). From Moby Dick to Free Willy: macro-cultural discourse and institutional entrepreneurship in emerging institutional fields. Organization, 11, 689-711.

Leitch, S. \& Davenport, S. (2002). Strategic ambiguity in communicating public sector change. Journal of Communication Management, 7(2), 129-139.

Liu, B.F., Horsley, J.S. \& Levenshus, A.B. (2010). Government and corporate communication practices: do the differences matter?. Journal of Applied Communication Research, 38(2), 189-213.

Maidani, E.A. (1991). Comparative study of Herzberg's two-factor theory of job satisfaction among public and private sectors. Public Personnel Management, 20(4), 441-448.

Markovits, Y., Davis, A.J., Fay, D. \& van Dick, R. (2010). The link between job satisfaction and organizational commitment: Differences between public and private sector employees. International Public Management Journal, 13(2), 177-196.

Mazza, C. (1998). The popularization of business knowledge diffusion: from academic knowledge to popular culture?. In J.L. Alvarez (Ed.). The Diffusion and Comsumption of Business Knowledge. London: Macmillan Press.

Meier, K.J. \& O'Toole, L.J. (2011). Comparing public and private management: Theoretical expectations. Journal of Public Administration Research and Theory, 21, 283-299.

Meyer, M. (2009). Retorik. Ankara: Dost Yayınları.

Mintzberg, H. (1975). The manager's job: folklore and fact. Harvard Business Review, July-August, 49-61.

Neuendorf, K.A. (2002). The Content Analysis Guidebook. Thousand Oaks: Sage Publications.

Öker, H. (2003). Şekilsel kalite başarılı olamaz!. Önce Kalite, Mayıs, 32.

Özen, Ş. (1999). Türkiye'deki guru söylemi modasının nedenleri. Siyasal Bilgiler Fakültesi Dergisi, Vol.54, No.1, 97-121.

Özen, Ş. (2002). Toplam kalite yönetiminin Türkiye'de yeniden kurgulanması: koşul bağımlı türdeşleşme tezinin bir testi. Amme İdaresi Dergisi, 35(1), 105-42.

Özen, Ş. \& Berkman, Ü. (2007). Cross-national reconstruction of managerial practices: TQM in Turkey. Organization Studies, (28), 825-851.

Powell, T.C., Lovallo, D. \& Fox, C.R. (2011). Behavioral strategy. Strategic Management Journal, 32, 1369-1386.

Rainey, H.G. \& Bozeman, B. (2000). Comparing public and private organizations: empirical research and the power of the a priori. Journal of Public Administration Research and Theory, 10(2), 447-469.

Rainey, H.G., Pandey, S. \& Bozeman, B. (1995). Research note: public and private managers' perceptions red tape. Public Administration Review, 55(6), 567-574.

Redman, T. \& Mathews, B.P. (1997). What do recruiters want in a public sector manager?. Public Personnel Management, 26(2), 245-256.

Ring, P.S. \& Perry, J.L. (1985). Strategic management in public and private organizations: implications of distinctive context and constraints. Academy of Management Review, 10(2), 276-286.

Rüling, C. (2005). Popular concepts and the business management. Scandinavian Journal of Management, 21, 177-195.

Sahlin-Andersson, K. (1996). Imitating by editing success: the construction of organizational fields (pp.13-48). In B. Czarniawska \& G. Sevon (Eds.). Translating Organizational Change. Berlin: Walter de Gruyter.

Sahlin-Andersson, K. \& Engwall, L. (2002). Introduction (pp.3-32). In K. Sahlin-Andersson \& L. Engwall (Eds). The Expansion of Management Knowledge: Carries, Flows and Sources. California: Stanford University Press.

Sarı, D. (2003). Eğitimde toplam kalite yönetimi. Önce Kalite, Eylül, 37.

Scarbrough, H., Robertson, M. \& Swan, J. (2005). Professional media and management fashion: the case of knowledge management. Scandinavian Journal of Management, 21, 197-208.

Suddaby, R. \& Greenwood, R. (2005). Rhetorical strategies of legitimacy. Administrative Science Quarterly, 50(1), 35-67.

Symon, G. (2000). Everyday rhetoric: Argument and persuasion in everyday life. European Journal of Work and Organizational Psychology, Vol.9, No.4, 477-488.

Tavşancıl, E. \& Aslan, E. (2001). Sözel, Yazılı ve Diğer Materyaller İ̧in İçerik Analizi ve Uygulama Örnekleri. İstanbul: Epsilon Yayınevi.

Uzer, T. (2002). Söyleşi. Önce Kalite, Kasım, 8(61), 20.

Üsdiken, B. (1997). Importing theories of management and organization. International Studies of Management and Organization, 26(3), 3346.

von Koskull, C. \& Fougere, M. (2011). Service development as practice: a rhetorical analysis of customer-related arguments in a service development project. Scandinavian Journal of Management, 27, 205-220.

Wilkins, B.M. \& Andersen, P.A. (1991). Gender differences and similarities in management communication: a meta-analysis. Management Communication Quarterly, 5(1), 6-35.

Yıldırım, E. (1999). Modern management techniques in the developing world: the case of TQM and its impact on workers in Turkey. Work, Employment \& Society, 13(4), 693-709. 